\title{
Floristic composition and turnover analysis in Dahomey Gap and the surrounding sub-humid Togolese mountain minor forest refuges: importance for biogeography and biodiversity conservation in sub-Saharan Africa
}

\author{
Kossi Adjossou ${ }^{1}$, Kouami Kokou ${ }^{2}$, and Marc DECONCHAT ${ }^{3}$ \\ ${ }^{1} \mathrm{UNI}$ \\ ${ }^{2}$ Université du Lomé \\ ${ }^{3}$ UMR DYNAFOR
}

March 3, 2022

\begin{abstract}
Aims Although minor climatic forest refuges were important as key areas for the long-term persistence of species and genetic diversity, and can again function as refuges during present and future climatic changes, they have received little attention in subSaharan Africa. The objectives in this paper were to assess the Togolese montane riparian forests as minor sub-Saharan forest refugia, examine the contribution of minor sub-Saharan forest refugia to the larger forest refugia using the Togolese montane riparian forests as a model, and discuss the implication of these results for biogeography and forest biodiversity conservation in sub-Saharan tropical Africa based on the floristic approach. Location Southwest Togo, West Africa, sub-Saharan Upper Guinea Region Methods Floristic data were collected across Togolese mountain riparian forests through an intensive botanical inventory using the survey approach $(\mathrm{n}=198 ; 50 \times 10 \mathrm{~m} 2)$. A comparative analysis was performed on the basis of floristic criteria and attributes related to climatic forest refuges. Results According to floristic attributes, the riparian forests of the subhumid Togolese mountains were important minor refuges for rainforests during Pleistocene warming. They share about $60 \%$ of their current species richness (868 species) with the large sub-Saharan forest refuges. Main conclusions The floristic data were similar to that of previous studies focusing on the forest refugia around the DG and elsewhere worldwide. However, they seem to be incompatible with the ideas that the DG forest flora may be essentially a relic of the early Holocene, when the geographical distribution of the Guinean-Congolian forest was maximum. Efforts to maintain maximum species diversity in sub-Saharan Africa should therefore pay particular attention to the conservation of minor forest refugia. This study asks important questions about the patterns of disjunction, which should be focused on in further studies. Keywords Tropical biodiversity, Forest refuges, Floristic approach, Dahomey Gap (DG), Togolese Mountain, Vegetation
\end{abstract}

\section{Hosted file}

KOADJ_1_1.doc available at https://authorea.com/users/463423/articles/558514-floristiccomposition-and-turnover-analysis-in-dahomey-gap-and-the-surrounding-sub-humid-togolesemountain-minor-forest-refuges-importance-for-biogeography-and-biodiversity-conservationin-sub-saharan-africa

\section{Hosted file}

Figures.docx available at https://authorea.com/users/463423/articles/558514-floristiccomposition-and-turnover-analysis-in-dahomey-gap-and-the-surrounding-sub-humid-togolese- 
mountain-minor-forest-refuges-importance-for-biogeography-and-biodiversity-conservationin-sub-saharan-africa 